اندازهگيرى آزمايشخاهى ضريب بـاى تلماسه ها و مقايسه آن با مقادير براوردى مدل

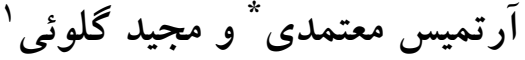

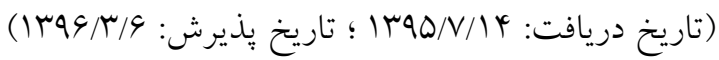

جكيده

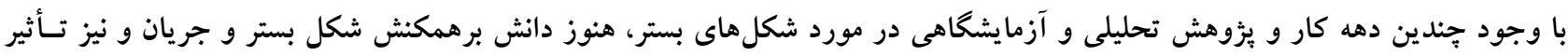

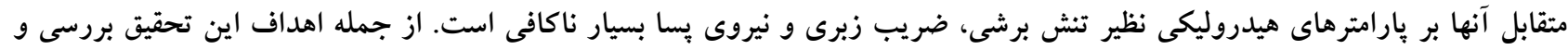

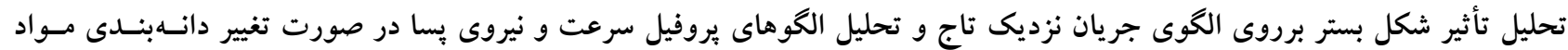

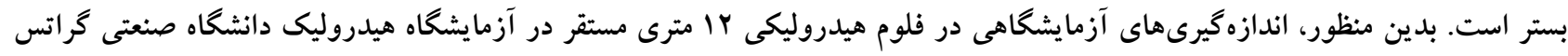

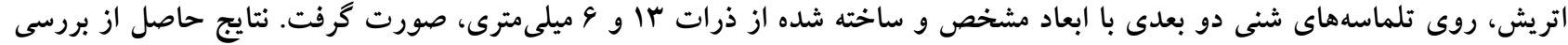

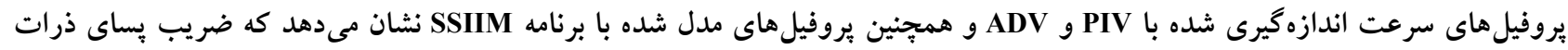

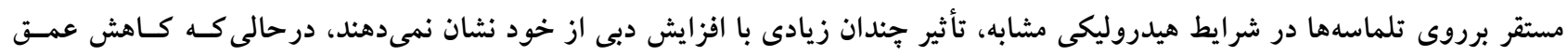

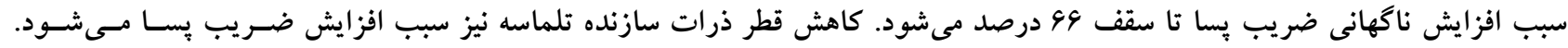

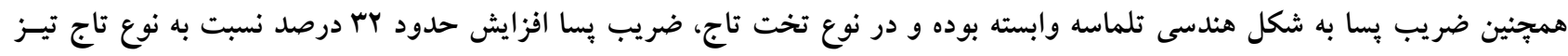

وازههاى كليدى: هندسه تلماسه، ضريب بسا، سرعت برشى، ميانخين دوكانه 

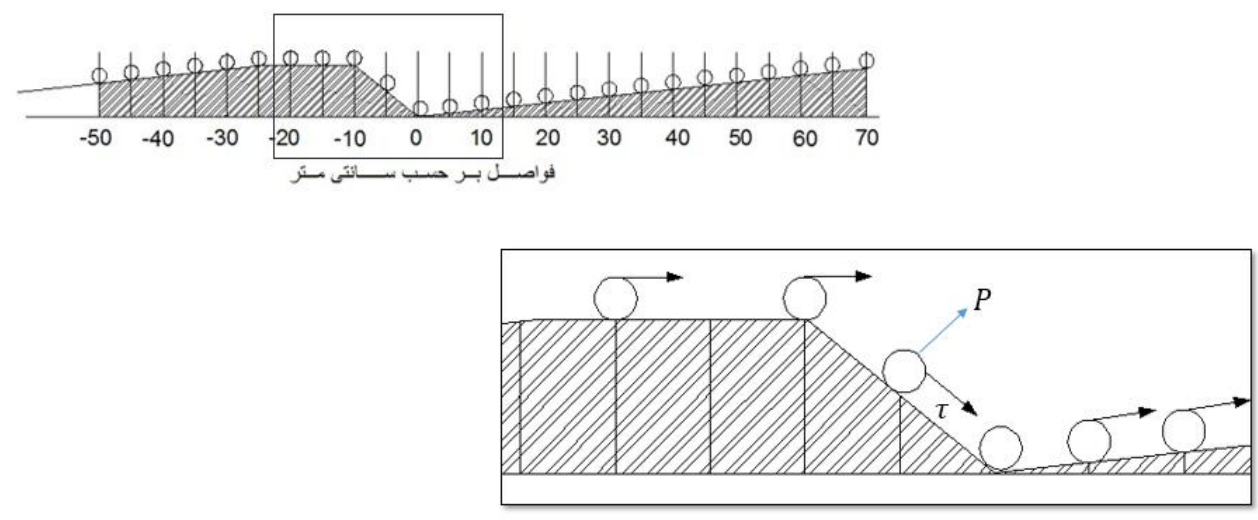

شكل 1. شكل شماتيك از ذرات بستر و نيروهاى وارد برآن

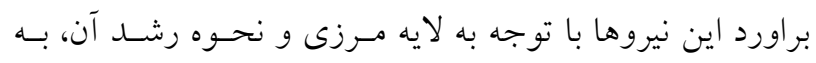

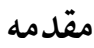

الخوى جريان در بيرامون جسم بستخى دارد.

رودخانهها همواره داراى شكل هاى مختلفى از بستر هستند. اين

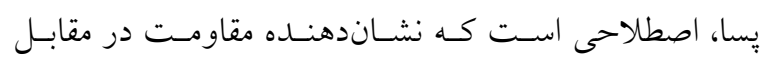

جريان است و به انواع پِساى فشارى (ناشى از عدم تعادل فشار

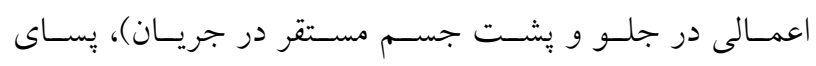

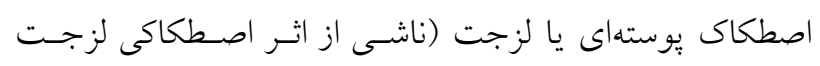

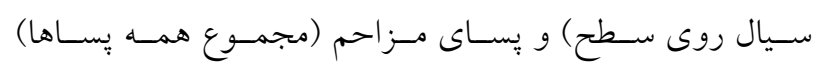

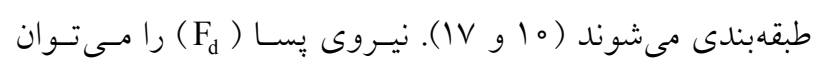

براى ذره با مساحت (A ) بلصصورت معادله ( (1) ارائه نمود:

$F_{d}=\int(P \sin \theta+\tau \cos \theta) d A$

ميزان يُا به نوع جريان وابسته است ولى متأسـفانه در بسـيارى

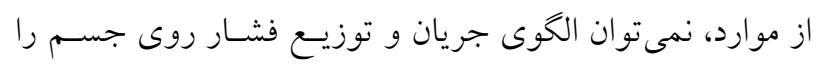

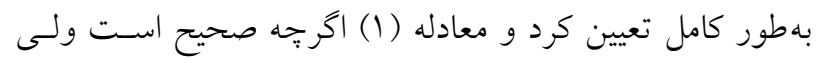

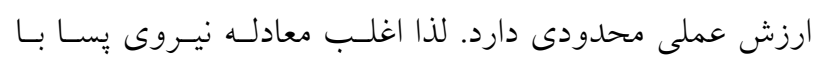

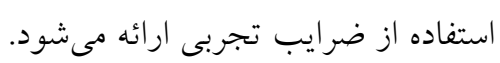

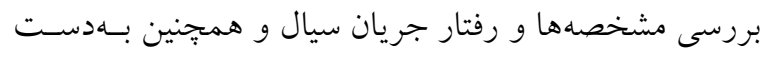

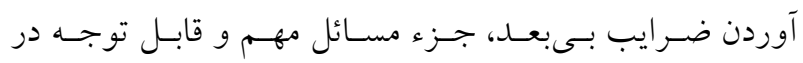

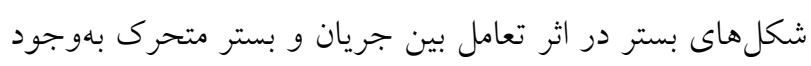

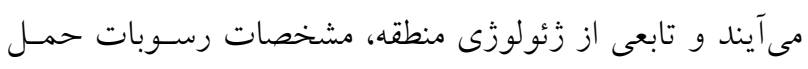

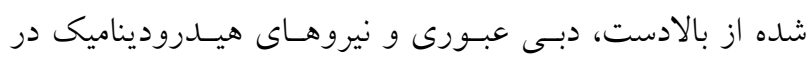

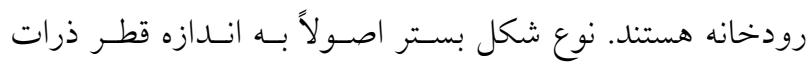

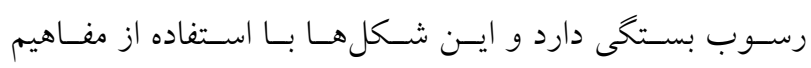

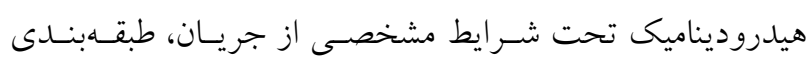

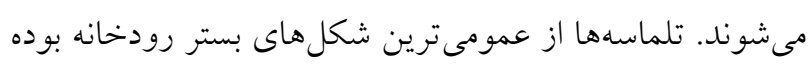

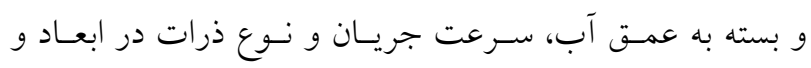

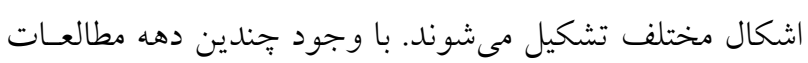

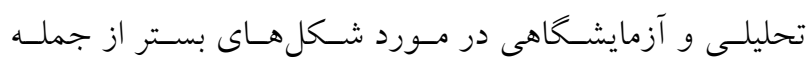

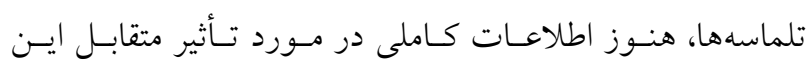

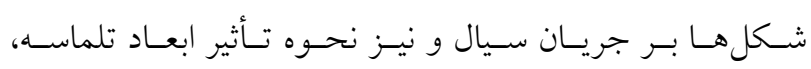

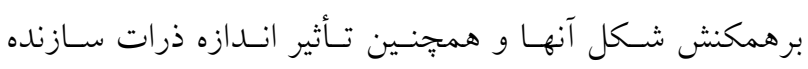

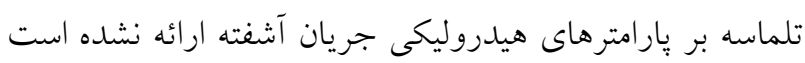

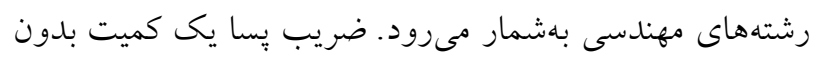

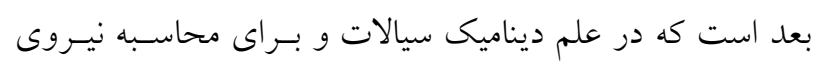

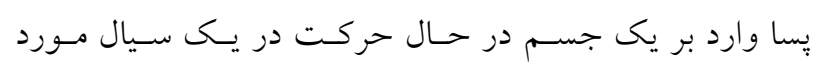

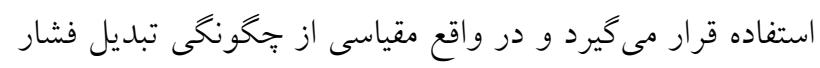

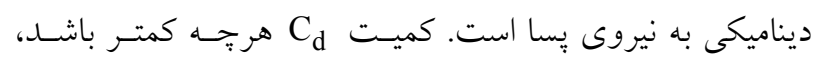

اجسام قرار كرفته در جريان سيال، همواره از جانـب سـيال تحت تأثير نيرويى هستند كه به جسم وارد مى شود. مؤلفـه ايسن

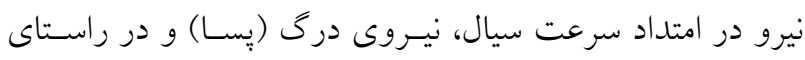

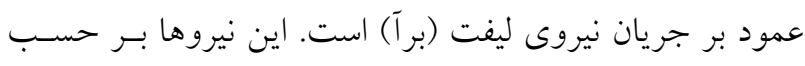
تنشهاى فشارى ( P ) و برشى ( ) بيان مسى يــوند (شـكل (1). 
مطالعات مربوط به ضريب پِّـا در رودخانـهــا تـاكنون اغلـب

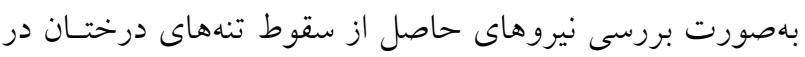

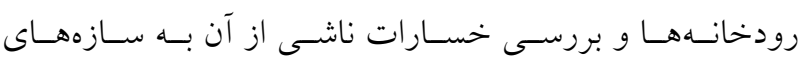

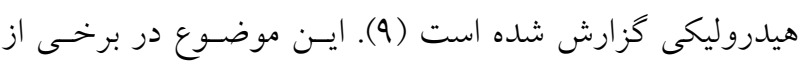

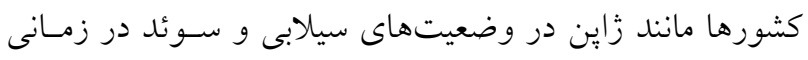

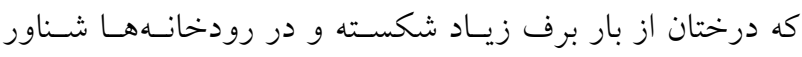
مىشوند، بسيار مهم است. مطالعات متعدد در اين زمينه نشـان مىدهد، نيروى بِاى حاصل بر تنههاى شناور و يا غوطهور بـا

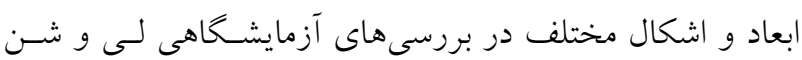

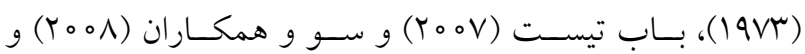
بررسى هاى صحر ايى وندر و همكاران (Y0|r)، تاناك و ياگيزوا

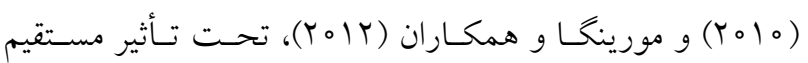

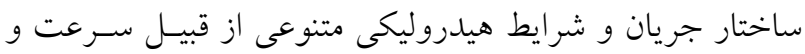

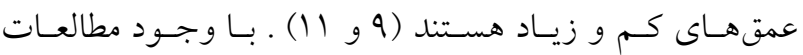
تجربسى و عسددى متعـدد در خصسوص تغييـر ضـريب يسـا در

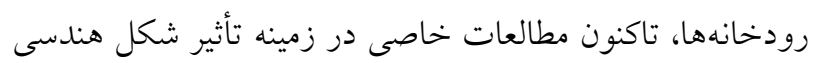

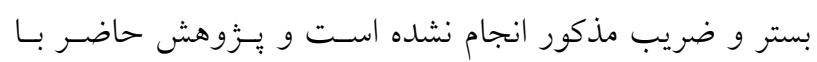

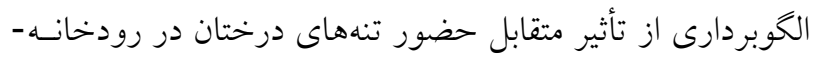

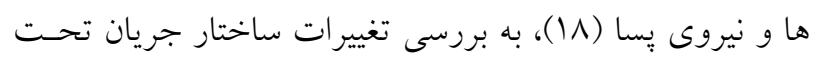
تأثير شكل هاى بستر مى يردازد.

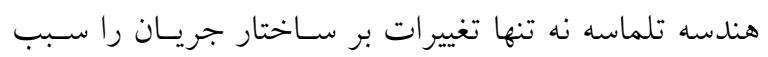

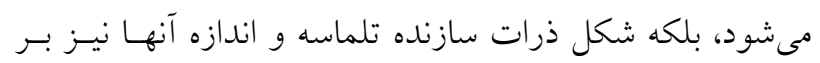

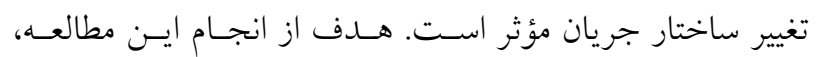

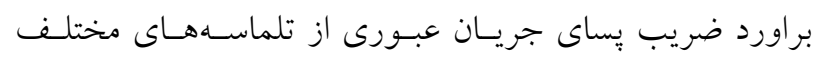

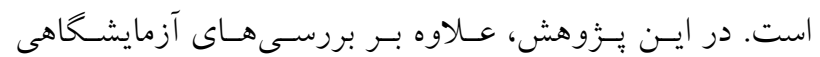

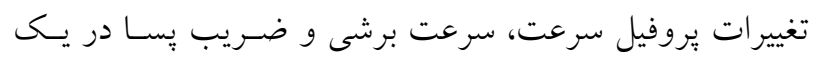

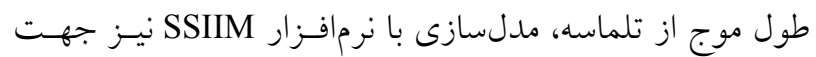

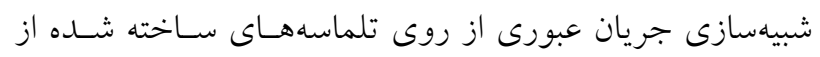
ذرات شن (با فرض كروى بودن آنها) نيز انجام شده است.

\section{مواد و روشها}

در اين تحقيق با ساخت 9 تلماسه مصنوعى بهصـورت متنـاوب
مطلوبتر است.

اين كميت بهصورت رياضى به شكل زير قابل تعريف است (IV):

$c_{d}=C D=\frac{r F_{d}}{\rho v^{r} A}$

در اين رابطـه: حركت سيال و A سطح مقطع عبور سيال است. ضريب بِا براى صفحه تخت در لايه مـرزى آرام برابـر بـا

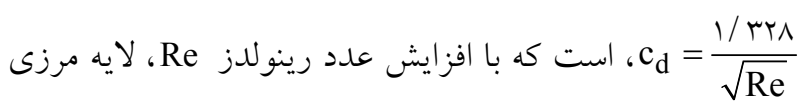

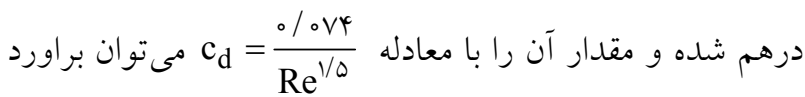
كرد. در حالتهاى سلبعدى و براى ذرات كروى شكل، ضريب

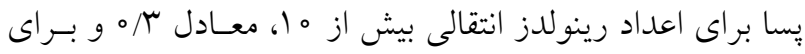

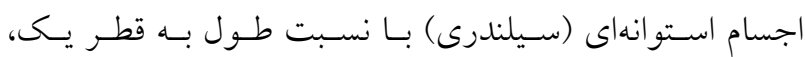

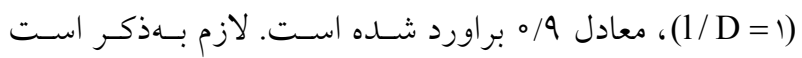
تمامى معادلات تجربى مذكور در بستر صاف، حاصل شدهاندو و تاثير شكل بستر ناديده گرفته شده است (م ا و IV).

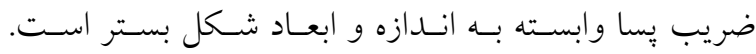

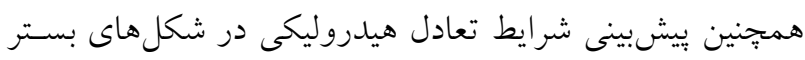

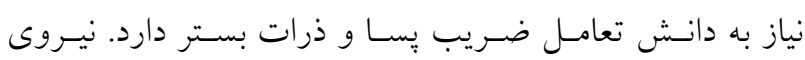

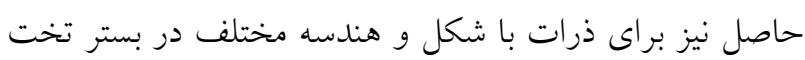

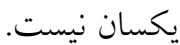

$\tau=\frac{F_{d}}{A} ; \quad \rho U^{* r}=\frac{1}{r} \rho V^{r} \times C_{d} \times \sin \alpha$ كه در آن، F⿸⿻一丿火

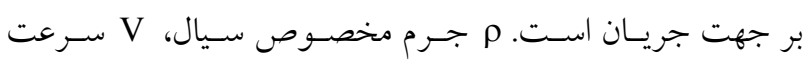

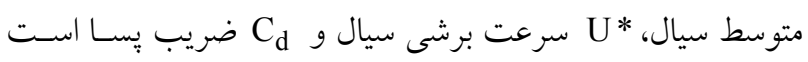

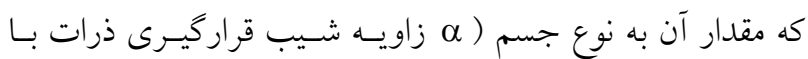

سطح افق) وابسته است كه بهطور تجربى تعيين مىشود (19) (19).

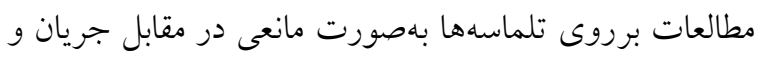

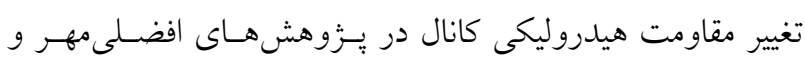

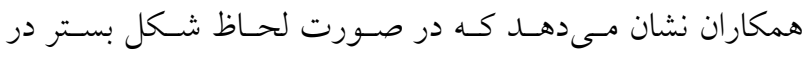
مطالعه، بيش از Do درصد مقاومت جريان ناشى از اثر شكل بستر بوده و فقط تا مب درصد ناشى از اندازه زبرى ذره است (†). 

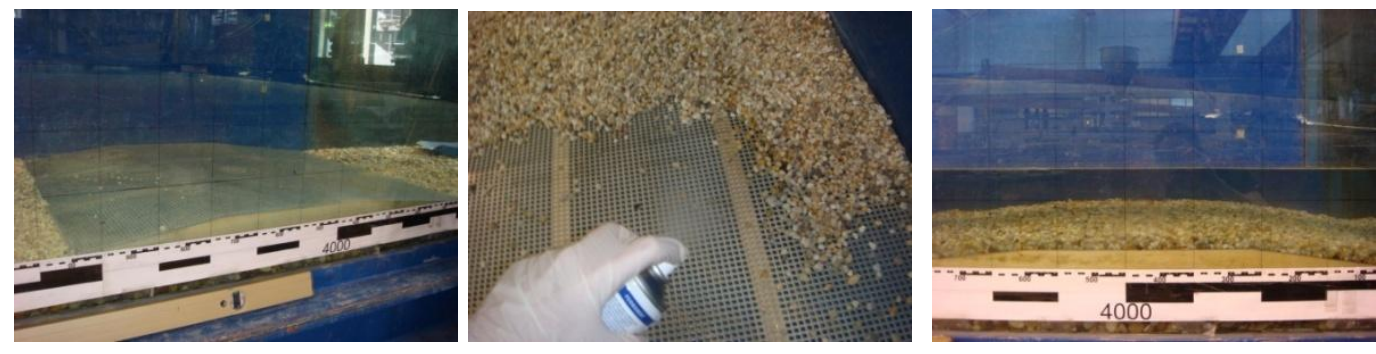

شكل r. استفاده از قالب جوبى - فلزى و نحوه ثابت كردن ذرات بستر

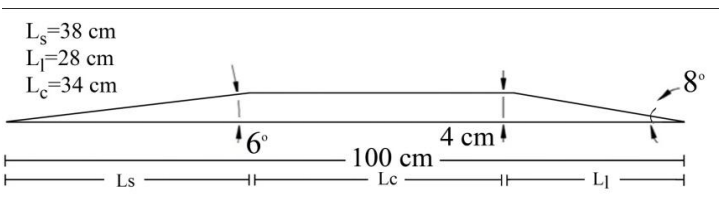

تلماسه تاج تخت

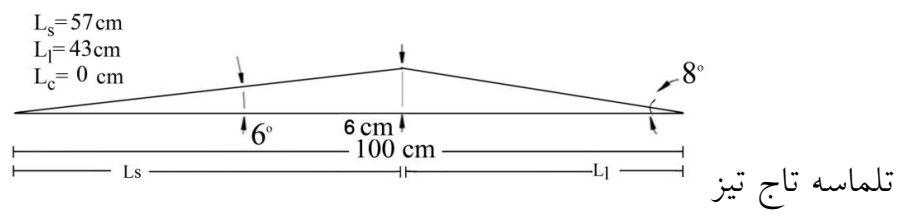

شكل r. انواع تلماسهاى ساخته شده در آزمايشخاه

و طول موجشان از ه/ه متر تا جند هزار متر گزارش شده اسـت

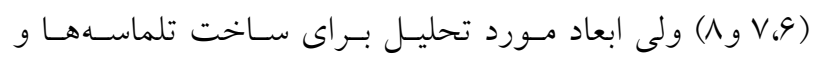
توسـعه آنهـا در عـرض فلـوم و تـو الى آنهـا در طـول فلـوم از

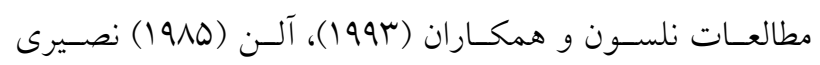

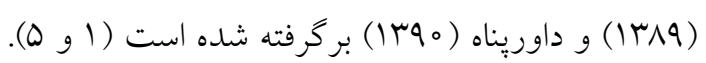
تلماسههاى تاج تخت داراى طـول مـوج يـــ متـر، ارتفــاع

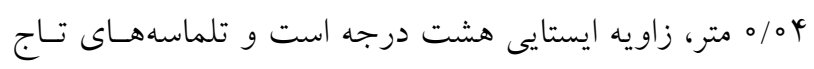

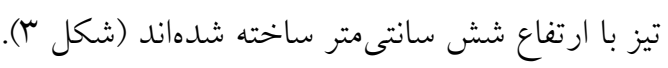

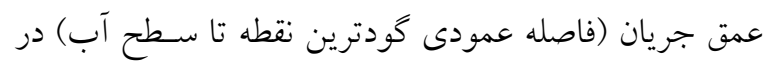

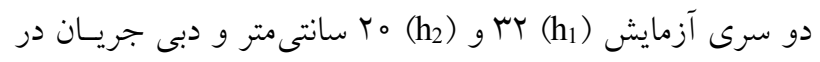
دو سرى آزمايش ديخر مبرو هو ليتر بر ثانيه در نظر گرفته شدند.

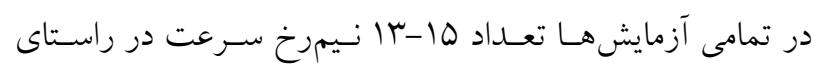

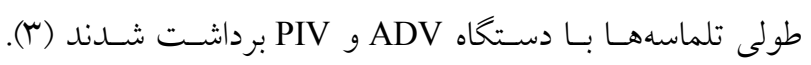

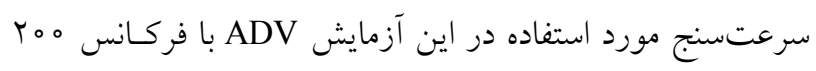

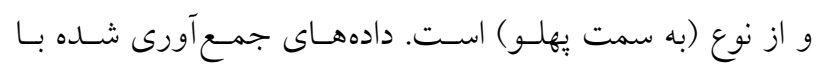
استفاده از نرمافـزار WinADV غربـال گثـته و يسس از آن مـورد تحليل قرار گرفتند. دستخاه PIV با شناسايى ذرات معلق در سيال،
در طول يك كانال آزمايشخاهى با مقطع مستطيلى بـه طـول

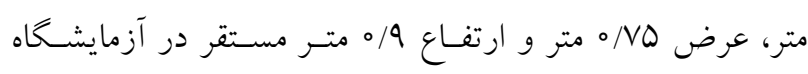

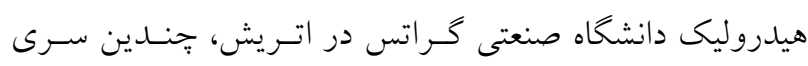

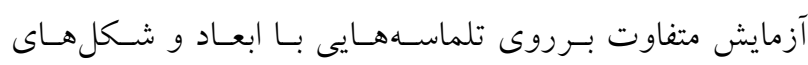

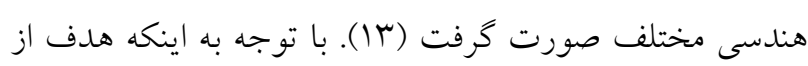

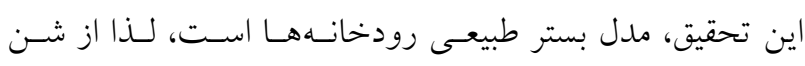

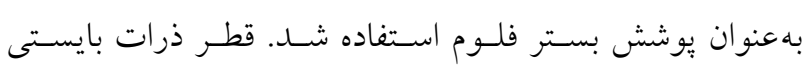

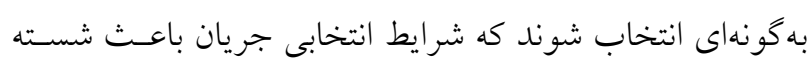
شدن و حركت دادن ذرات بستر نشـود. بـــين منظـور، شـرايط

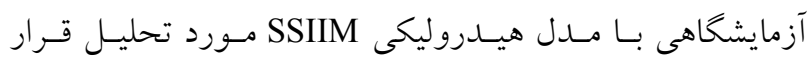
كرفت و قطر متوسط ذرات بستر، براورد شد. شن مورد استفاده براى ساختن تلماسهها با قطر متوسط حسدود با و و ميلـىمتـر

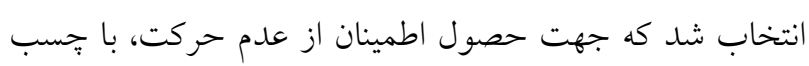
برروى تلماسههاى جوبى از ييش ساخته شده، ثابت شده (شكل

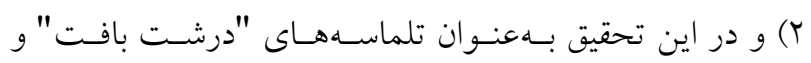
"ريزبافت " معرفى شدهاند. اخر جه ارتفاع تلماسهها از مقادير جند سانتى متر تا جند متـر 
سرعت آب كه بهمعناى استفاده از شرايط مرزى با كراديـان صـفر براى سرعتهاى سطح آب است، در نظر كرفته مى شيود.

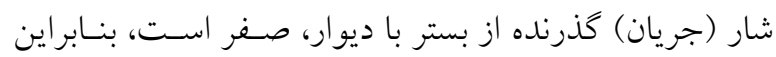

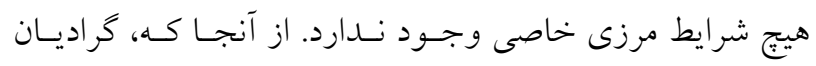

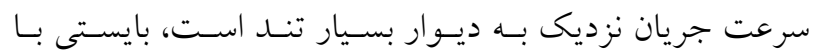

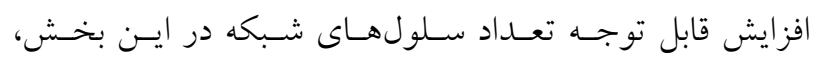
كراديان را تا مقدار قابل قبولى شبيهسازى كرد.

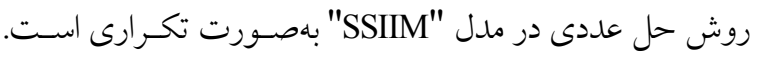

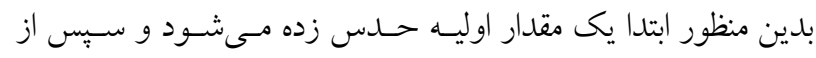

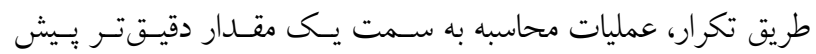

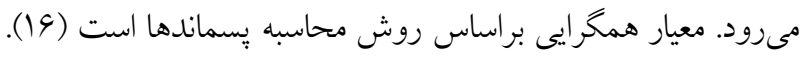

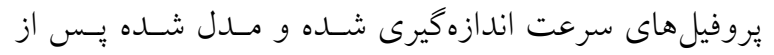
واسنجى مدل (با خطـاى كمتـر از هشـت درصـــ) ، در شـرايط

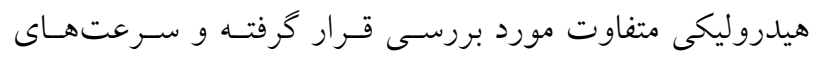

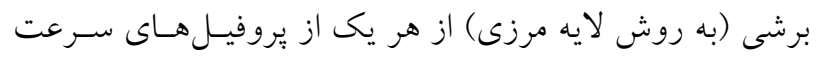

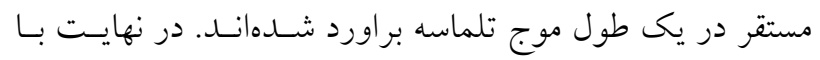

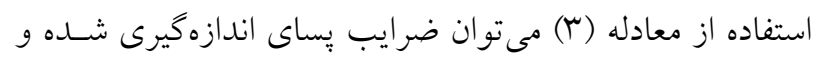

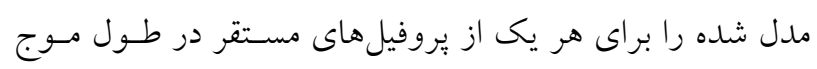

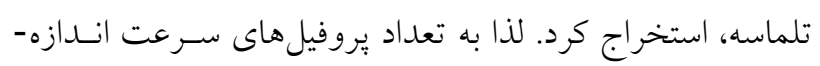

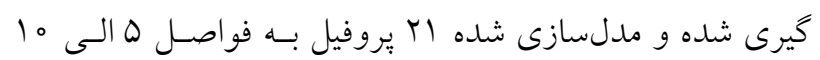

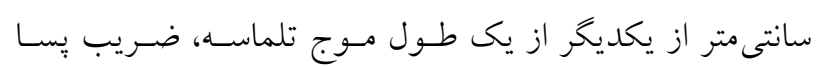
براورد مىشود.

بلهمنظور محاسبه ضريب يُاى ميانخين، سرعت برشى به كار

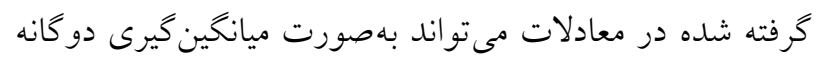

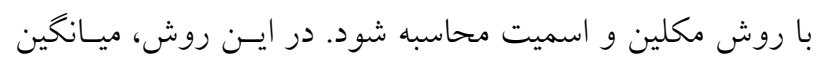

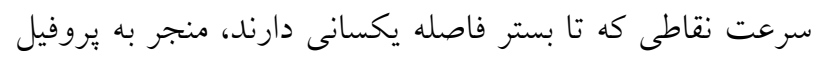

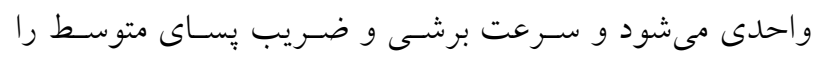

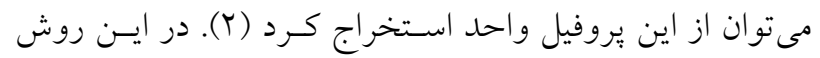

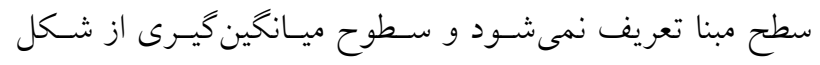

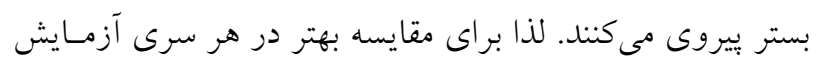

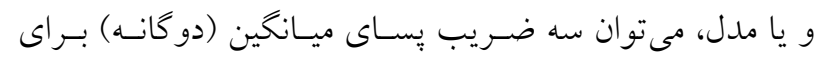
وجوه بالادست، ياييندست و تاج تلماسه استخراج كرد.
سـرعت جريـان عبـورى را تعيـين مسى كنـــ. بـا تنظيم فركـانس

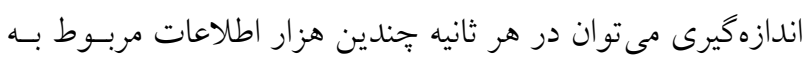
بردارهاى سرعت را برداشت كرد (r آو سار).

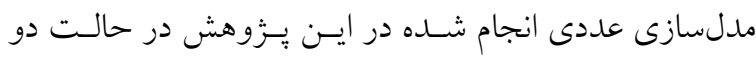

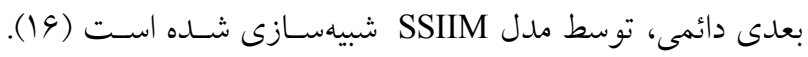

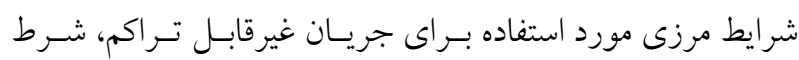
مرزى سرعت ورودى براى مرز بالادست جريان (ورودى كانال)،

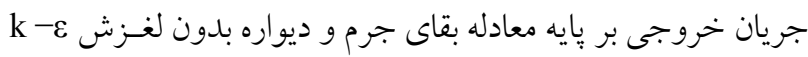

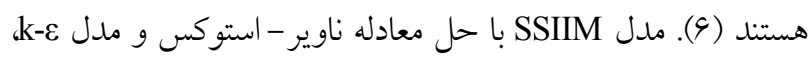

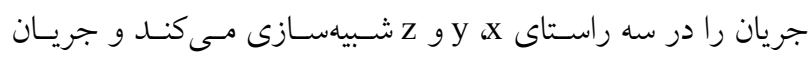

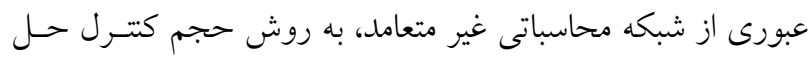

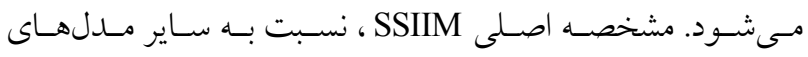

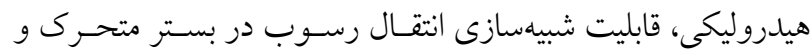

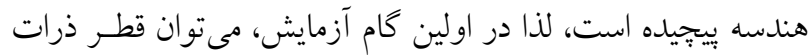

متتخب را براى ساخت يك بستر آب زلال مدلسازى كرد (19).

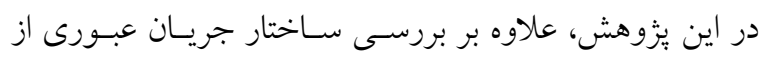

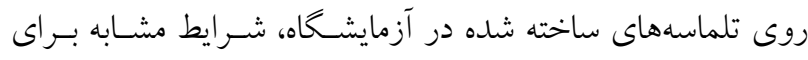

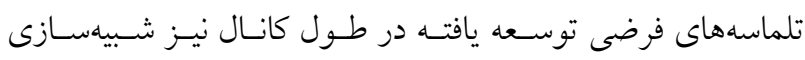

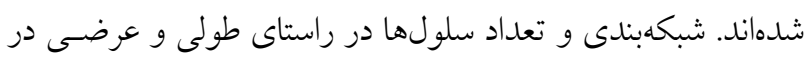

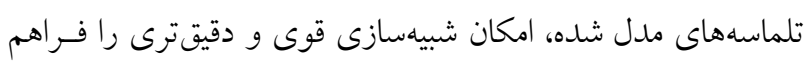

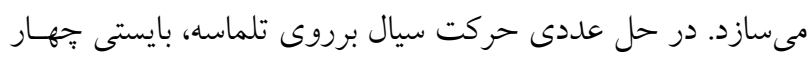

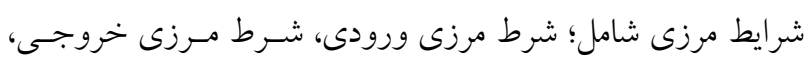
شرط مرزى سطح آب و شرط مرزى بستر يا ديوار مشخص شرط شودي.

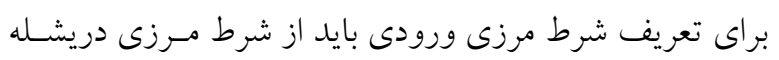

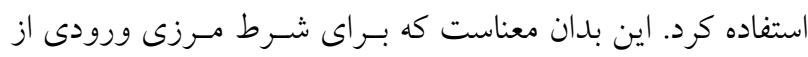

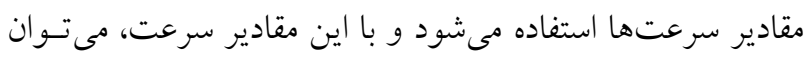
مقدار تنش برشى را در ورودى فلوم نيز تخمين زد.

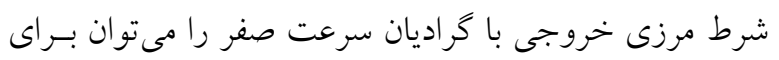

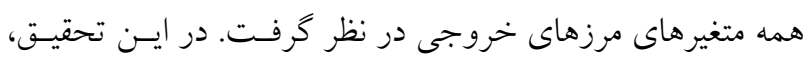

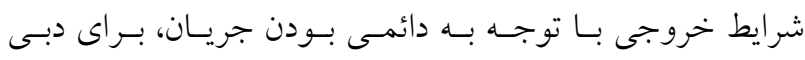

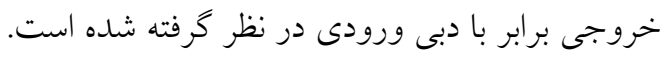

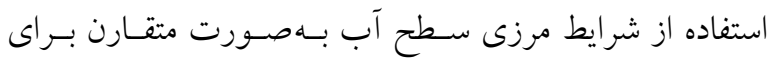


نشريه علوم آب و خاك (علوم و فنون كشاورزى و منابع طبيعى) / سال بيست و دو / شماره دو / تابستان IrqV

جدول ا. خلاصه شرايط هيدروليكى اعمال شده و مدل شده

\begin{tabular}{|c|c|c|c|c|}
\hline حداكثر سرعت جريان (cm/s) & عمق آب (cm) & دبى (lit/s) & نوع تلماسه & سرى \\
\hline 19 & MY & \multirow{3}{*}{$\mu_{0}$} & \multirow{5}{*}{ تلماسه تاج تخت } & 1 \\
\hline & & & & \\
\hline r4 & $r_{0}$ & & & $r$ \\
\hline ק & r & \multirow{2}{*}{90} & & r \\
\hline 99 & & & & 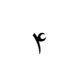 \\
\hline 19 & Tr & \multirow{2}{*}{$\mu_{0}$} & \multirow{5}{*}{ تلماسه تاج تيز } & 0 \\
\hline rq & $r_{0}$ & & & 9 \\
\hline & & \multirow{3}{*}{90} & & V \\
\hline 14 & $T T$ & & & V \\
\hline 99 & ro & & & $\wedge$ \\
\hline
\end{tabular}

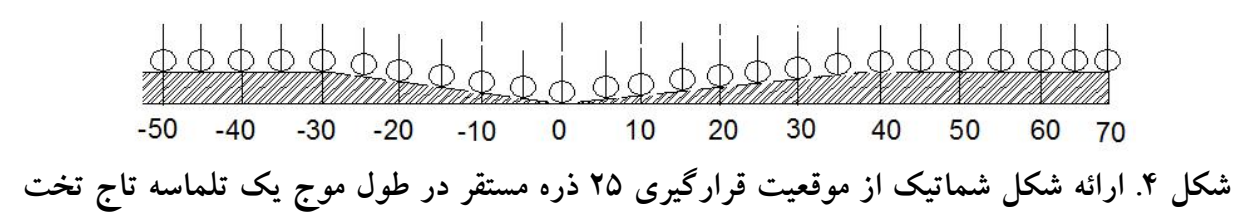

تغييرات ضريب يُسا در يك طول موج از تلماسه، براى شـرايط

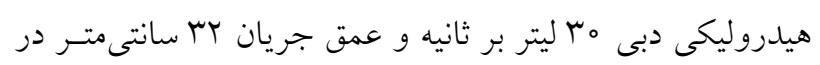
دو تلماسه تاج تخت و تلماسه تاج تيز در شكل (ه) ارائه شــه

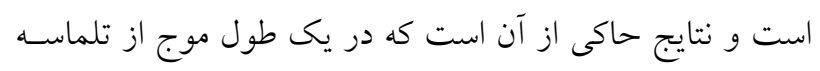

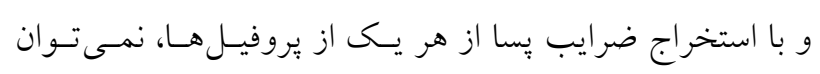

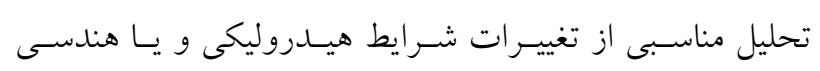

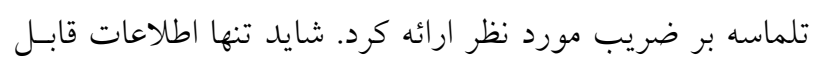

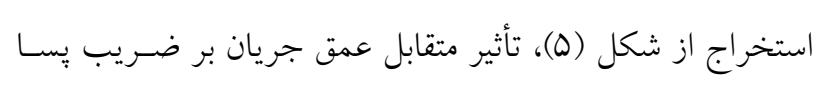

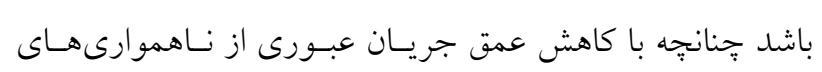
بستر، ضريب بـا افزايش مى يابد.

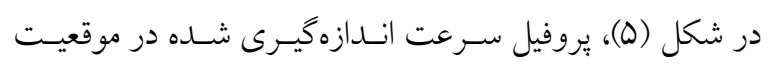

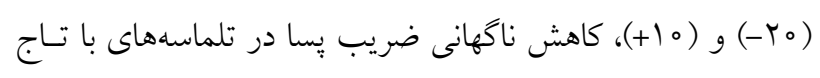

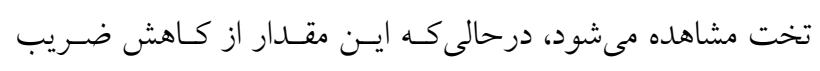
مذكور در تلماسههاى با تاج تيز كزارش نشده است. دليـل ايسن امر را مىتوان با اشاره به تحقيقات بيشين معتمــى و همكـاران

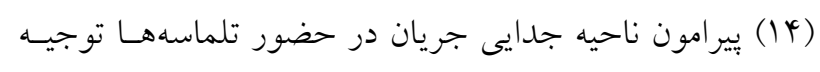
كرد. مـرور نتـايج حاصـل از آزمـايشهـاى انجــام شــده نشـان

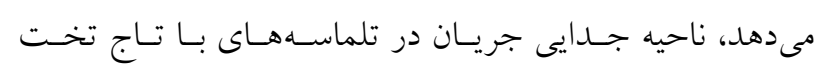

در اين تحقيق، نمودار ضريب يِـا بـراى تمـامى ذرات مسـتقر

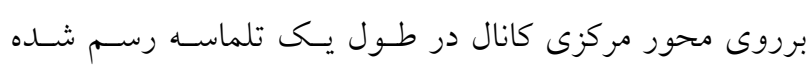

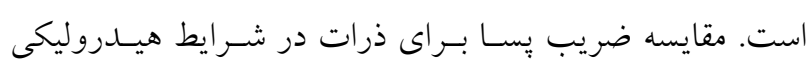

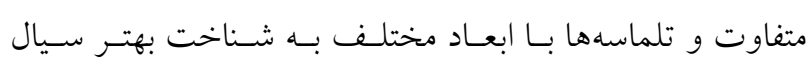
عبورى از روى كانال كمك مى كند.

نتايج شرايط هيدروليكى جريان عبورى برروى تلماسههـاى تـاج تخـت و

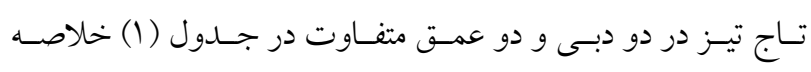

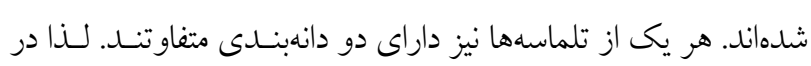
مجموع بس سرى آزمايش تجربى و عددى مورد تحليل قرار كرفت. بررسى ضريب يساى ذرات مستقر بـرروى تلماسـهــا، در طـول موج يكى تلماسه نشان مى دهد كه ها ذره به به فاصله ينج سانتى متسر

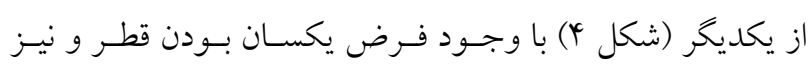
فرض مشابه بودن شكل هندسى كروى، طبق معادله (س)، ضـريب

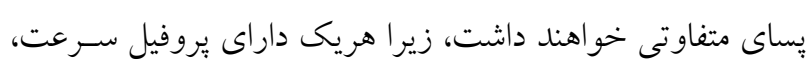
سرعت متوسط و سرعت برشى منحصر به فرد خود خواهند بـود. 

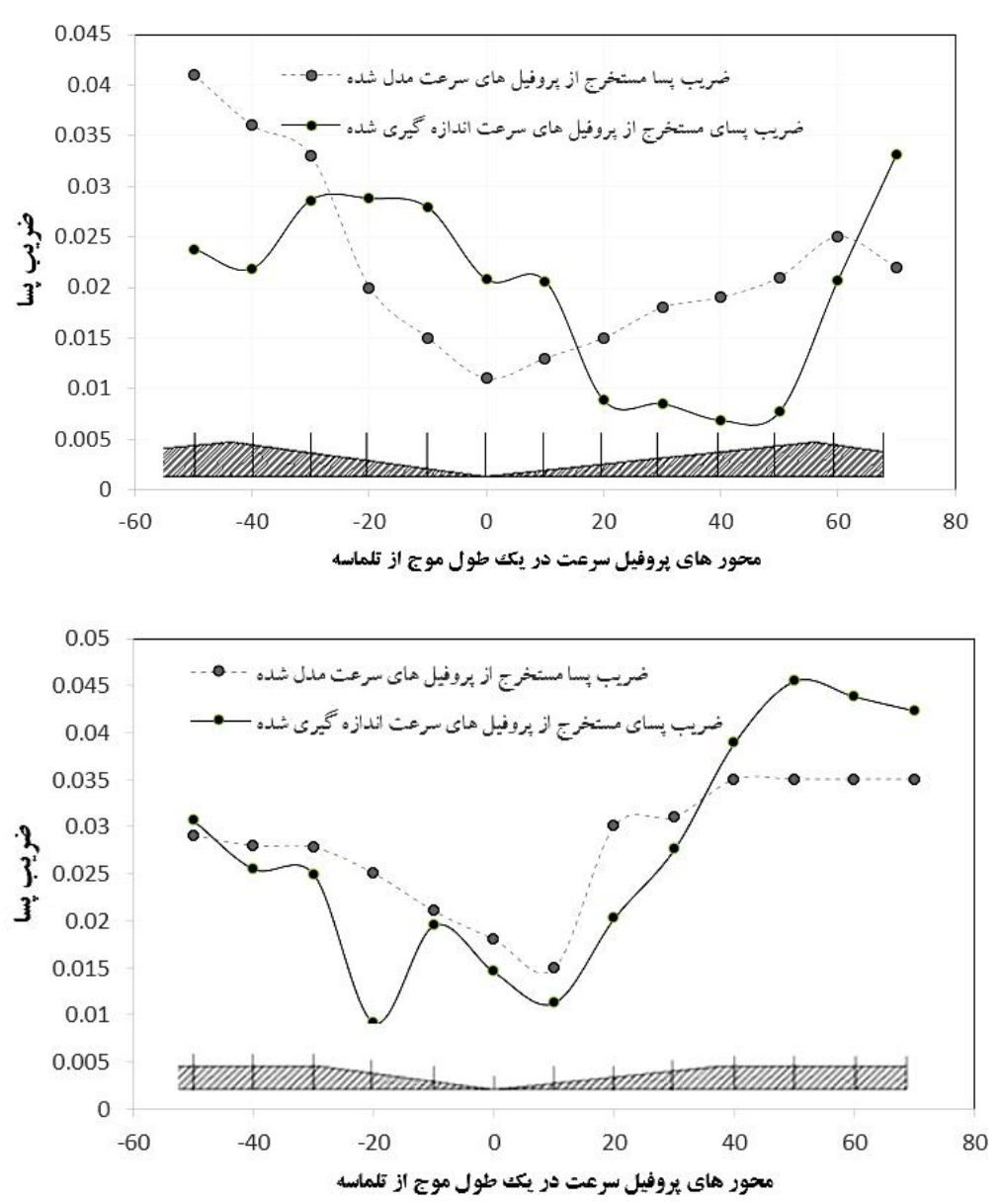

شكل ه. نمايش ضريب پِّا براى ذرات مستقر بر الف) تلماسه تاج تخت و ب) تاج تيز در شرايط هيدروليكى دبى مب ليتر بر ثانيه و عمق بrاسانتى برمتر

است، زيرا با افزايش عمق تلماسه از سـطح مقطع جريـان كـم مىشود و در دبى ثابت با افزايش سـرعت جريـان، نيسروى بِّـا بيشتر مىشود. در اين تحقيق بـا بررسى بروفيـلهـاى سـرعت حاصل شده از دستخاههاى سرعتسنج ADV و PIV مىتوان با

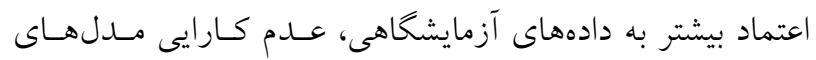
سادهاى همجون SSIIM در براورد ضريب يسا را بِيشبينى كرد. زيرا اين مدلها با فرض يكسان گرفتن شكل و قطر ذرات بستر، در تحليل جريان عبورى از تلماسه و لايه مرزى نزديك بسـتر و

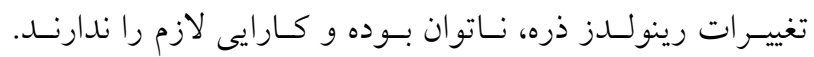

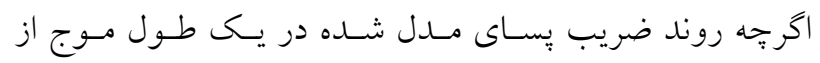
تلماسه تقريباً با روند ضريب اندازهذيـرى شــده مـذكور مشـابه است، ولى بهنظر مىرسد مقادير مدل شـــه داراى خطـا بـوده و
بسيار كوجّىتر از ناحيه جدايى جريان در تلماسههـاى بـا تـاج

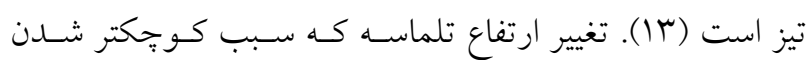
ناحيه جدايى جريان مىشود، سبب كاهش ناگهانى ضريب يسـا شده و آن را تاسقف هو درصد كاهش مىدهـد. افـت فشـار در ناحيه جدايى جريان جلو و بشت شكل بستر، سبب عدم تعـادل بين نيروهاى بالادست و باييندسـت شـكل بسـتر شـده كـه در نهايت موجب افزايش نيروى بِا مسى شـود. زمـانى كـه ارتفـاع

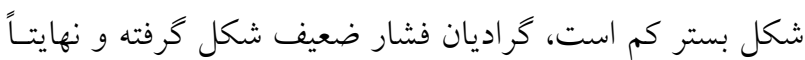
منجر به كاهش ناحيه جدايى جريان مىشود. نتيجه ديخر مستخرج از شكل (ه)، ارائه عدم تطابق ضسريب يساى مدل شده و اندازهيرى شده است. بهنظـر مسىرســ كـه دادههاى SSIIM در زمينه نيروى يُا به واقعيت بيشـتر نزديـك 


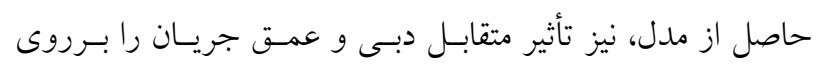
ضريب بسا تأييد مى كند.

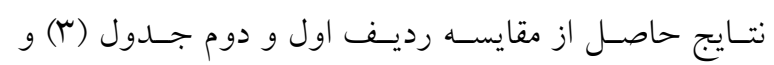

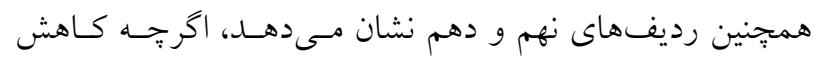

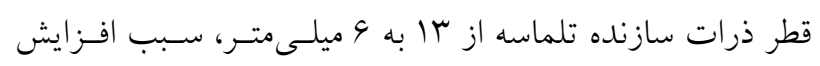

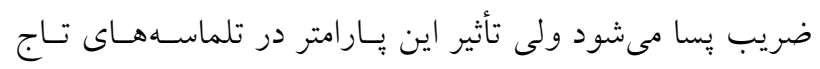

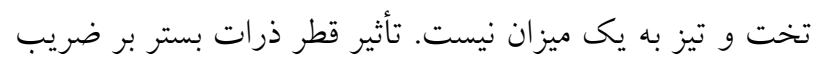

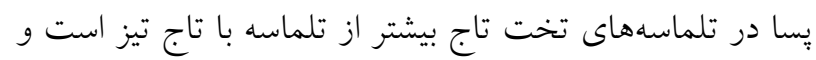

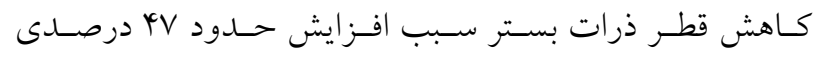
ضريب بـا در تلماسههاى تاج تخت شده، درحالى كـه افـزايش

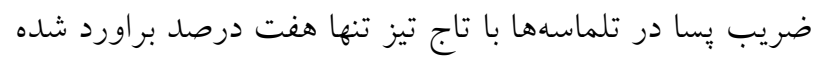

در ايسن راسـتا نتـايج حاصـل از بررسـى شـكل هندسىى

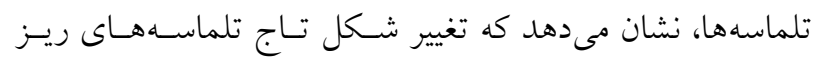

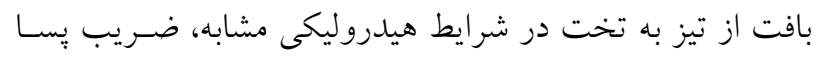

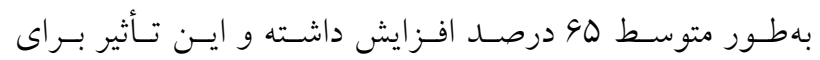

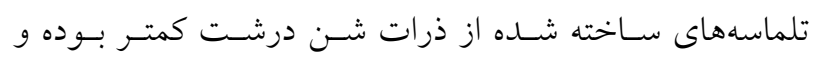

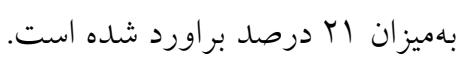

\section{نتيجه گيرى}

در اين تحقيق، تغييرات نوسانى مؤلفههـاى سـرعت و همجنـين

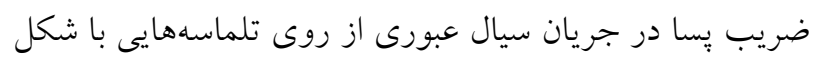

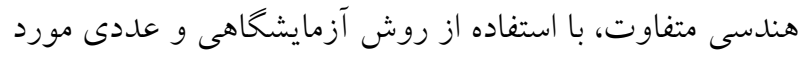

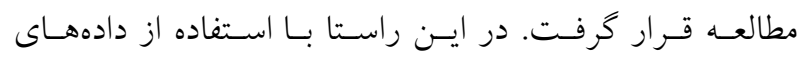

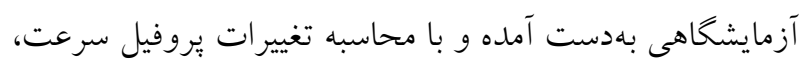

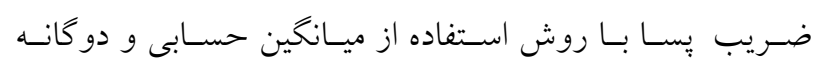

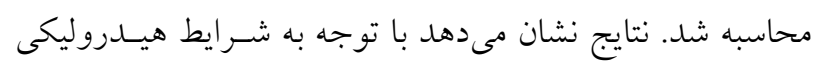

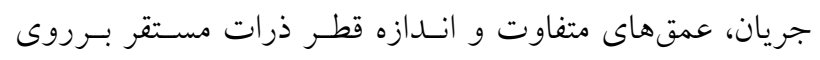

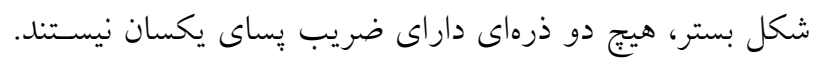

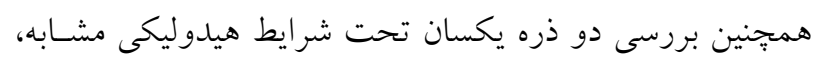
نشان داد كه شكل هندسى تلماسهها نيز به علـت تغييـر شـر ايط

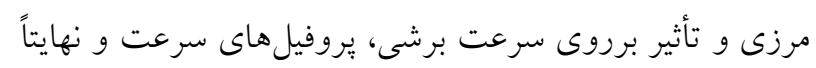

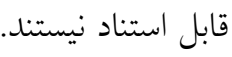

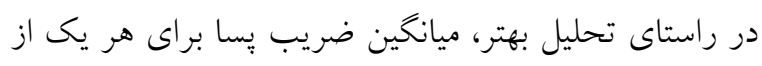

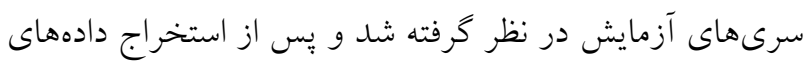

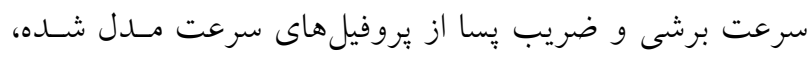

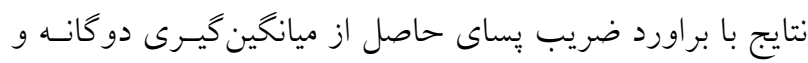

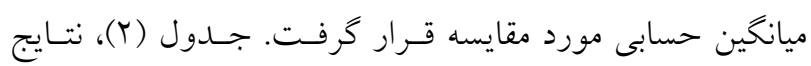

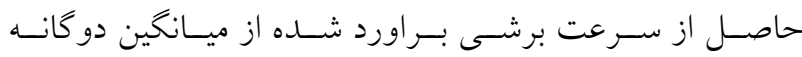

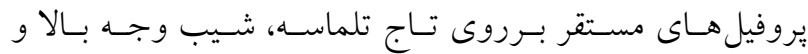

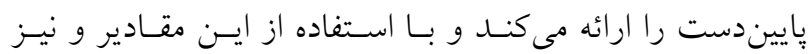

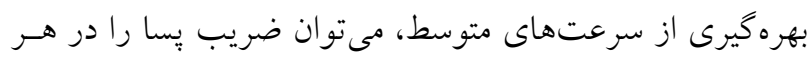

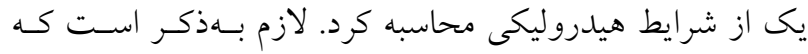

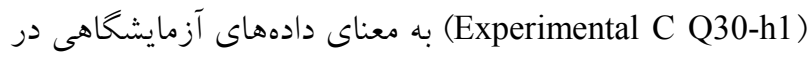
شر ايط دبى •T ليتر بر ثانيه و عمق Yr سانتىمتر هستند. يـارامتر

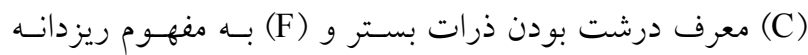
بودن ذرات بستر است.

هشت سرى از 19 آزمايش صورت كرفته بهصورت منتخب استب

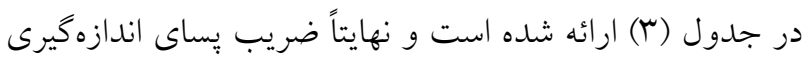

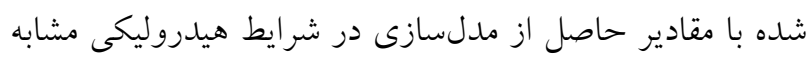

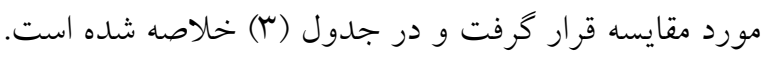

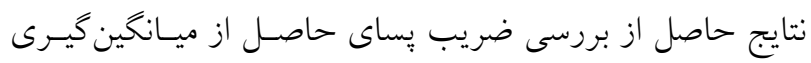

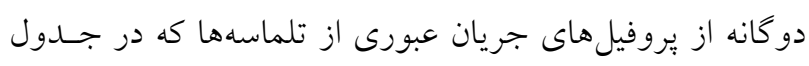

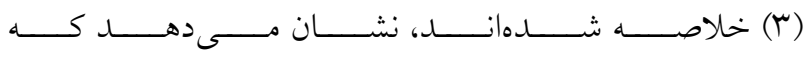
در تلماسههاى تاج تخــت و تيـز در شـــايط هيـدروليكى مشـابه،

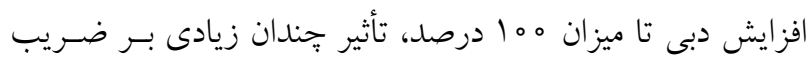

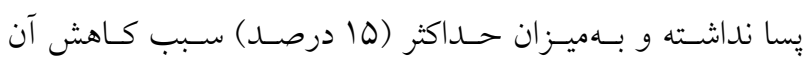
مىشود. اين رقم را مى توان با مقايسه رديف دوم و سـوم جـدول

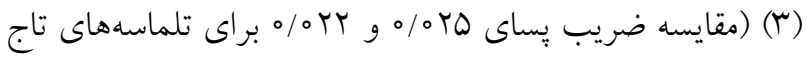

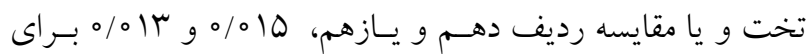

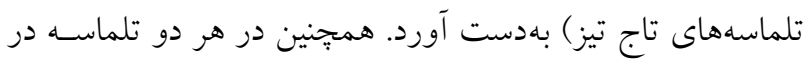

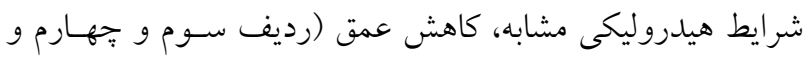

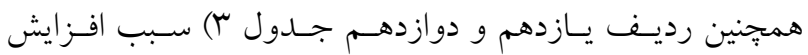
ناكهانى ضريب يُا تا سقف 99 درصسد مسى رشـود. نتـايج مشـابه 
جدول r. سرعت هاىبرشى (sm/s)، استخراج شده از بروفيلهاى واحد سرعت جريان عبورى از روى قسمتهاى مختلف تلماسه با تاج تخت

\begin{tabular}{|c|c|c|c|c|c|c|c|c|c|c|c|c|c|c|c|}
\hline-50 & -40 & -30 & -20 & 10 & 0 & 10 & 20 & & & 40 & 50 & 60 & 70 & & \\
\hline$-\infty \circ$ & $-r_{0}$ & $-r_{0}$ & $-Y_{0}$ & -10 & $\circ$ & $\circ$ & 10 & $r_{0}$ & $\mu_{\circ}$ & ro & Q० & 90 & V。 & $(-\infty \circ, V \circ)$ & \\
\hline \multicolumn{3}{|c|}{ تاج 1} & \multicolumn{3}{|c|}{ زايايندسيه وجه } & \multicolumn{4}{|c|}{ زاويه وجه بالادست } & \multicolumn{4}{|c|}{ تاج } & تميانگين روى & شر ايط هيدروليكى \\
\hline \multicolumn{3}{|c|}{$1 / 4 \circ 94$} & \multicolumn{3}{|c|}{ r/OY०Y } & \multicolumn{4}{|c|}{$1 / 00 \circ 9$} & \multicolumn{4}{|c|}{$1 / 49.9$} & $1 / 9 V Y A$ & Numerical C Q30-h1 \\
\hline \multicolumn{3}{|c|}{ I/AVAr } & \multicolumn{3}{|c|}{ I/Y4VV } & \multicolumn{4}{|c|}{ 1/QGKM } & \multicolumn{4}{|c|}{$1 / 1 \circ 91$} & $1 / 9 V+4$ & Numerical F Q30-h1 \\
\hline \multicolumn{3}{|c|}{ r/MYIO } & \multicolumn{3}{|c|}{ r/gr/Y } & \multicolumn{4}{|c|}{ 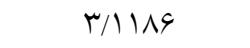 } & \multicolumn{4}{|c|}{$r / 4990$} & TMYAD & Q60-h1 Numerical F \\
\hline \multicolumn{3}{|c|}{$1 / \pi \Delta 1$} & \multicolumn{3}{|c|}{ INOTO } & \multicolumn{4}{|c|}{ I/TYVA } & \multicolumn{4}{|c|}{$1 / \Delta 914$} & 1/DHTI & Experimental C Q30-h1 \\
\hline \multicolumn{3}{|c|}{$r / 191 \Lambda$} & \multicolumn{3}{|c|}{ I/TOHT } & \multicolumn{4}{|c|}{$1 / 4 \times 90$} & \multicolumn{4}{|c|}{$r / Y \wedge 90$} & I/VN०K & Q30-h1 Experimental F \\
\hline \multicolumn{3}{|c|}{$r / \Delta V V \mu$} & \multicolumn{3}{|c|}{ r/Q } & \multicolumn{4}{|c|}{ r/०qR } & \multicolumn{4}{|c|}{ r/AMT。 } & T/MTEY & Experimental F Q60-h1 \\
\hline \multicolumn{3}{|c|}{ r/QRqR } & \multicolumn{3}{|c|}{$r / 1191$} & \multicolumn{4}{|c|}{ T/TMDQ } & \multicolumn{4}{|c|}{ T/GYQT } & T/99M & Q30-h2 Experimental F \\
\hline
\end{tabular}

جدول r. دامنه و مقدار متوسط ضريب بـا (ميانگين دو گانه و حسابى) در شرايط هيدروليكى متفاوت

\begin{tabular}{|c|c|c|c|c|}
\hline \multicolumn{5}{|c|}{ تلماسه تاج تخت } \\
\hline ميانخين دو گانه ضريب يسا & ميانخين حسابى ضريب يسا & دامنه ضريب يِسا & شرايط هيدروليكى & 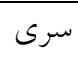 \\
\hline $0 / 01 \mathrm{~V}$ &.$/ 011$ & ०/००人-०/०५Y & Experimental Coarse Q30- $\mathrm{h}_{1}$ & 1 \\
\hline \% TQ & \% TV & $. / 009-0 / 040$ & Experimental Fine Q30-h1 & r \\
\hline O०YY & ס & $0 / 011-0 / 0 \mu \Lambda$ & Experimental Fine Q60-h1 & r \\
\hline $0 / 041$ & $\circ / 040$ & $\circ / 0 \circ \vee-0 / 09 \Lambda$ & Experimental Fine Q30-h2 & r \\
\hline D & \%०YQ & $\circ / \circ \nvdash \Lambda-\circ / \circ \vee \circ$ & Numerical Coarse Q30- $\mathrm{h}_{1}$ & 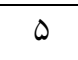 \\
\hline O/ Y^ & ०० Yq & $.010-0 / 0 \mu \Delta$ & Numerical Fine Q30-h1 & 9 \\
\hline$\circ / 0 Y \wedge$ & ०० Yq & $. / 010-0 / 0 T_{0}$ & Numerical Fine Q60- $\mathrm{h}_{1}$ & v \\
\hline \%०К & $0 / 041$ & $0 / 0 \mu Y-0 / 091$ & Numerical Fine Q30- $\mathrm{h}_{2}$ & $\wedge$ \\
\hline \multicolumn{5}{|c|}{ تلماسه تاج تيز } \\
\hline $0 / 014$ &.$/ 010$ & ०/००Y-0/०YY & Experimental Coarse Q30- $\mathrm{h}_{1}$ & 9 \\
\hline .010 & $0 / 019$ & 0/009-0/0r & Experimental Fine Q30- $\mathrm{h}_{1}$ & $1 \circ$ \\
\hline $0 / 011$ & $0 / 014$ & O/OOY-O/OYT & Experimental Fine Q60- $\mathrm{h}_{1}$ & 11 \\
\hline ०० Yq & O/OH & $0 / 010-0 / 09 \mathrm{~V}$ & Experimental Fine Q60- $\mathrm{h}_{2}$ & ir \\
\hline.$/ 01 V$ & $0 / 019$ & $0 / 0 Y M-0 / 090$ & Numerical Coarse Q30-h & Ir \\
\hline \%०५० & OOTt & $0 / 011-0 / 041$ & Numerical Fine Q30- $\mathrm{h}_{1}$ & if \\
\hline$\circ / 0 Y_{0}$ & O/OTY & $0 / 011-0 / 041$ & Numerical Fine Q60-h1 & 10 \\
\hline $0 \%$ & 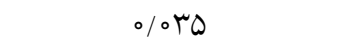 & $\circ / \circ Y \Lambda-\circ / \circ \Delta Y$ & Numerical Fine Q60- $\mathrm{h}_{2}$ & 19 \\
\hline
\end{tabular}


افزايش در بستر شنى ريز 90 درصد و در بستر شنى درشت ال درصد براورد شده است.

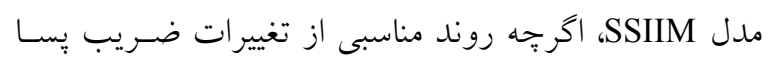
در طول موج تلماسه ارائه مى كند ولى بـهسبب يكسـان فـرض كردن قطر و شكل ذرات بسـتر، در تحليـل ضـريب يسـا داراى خطا بوده و به نظر مىرسد مدل جندان مناسبى نيست. با توجه به نوين بودن موضـوع تحقيـق، بيشـنهاد مسىشـود،

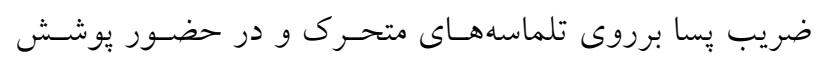

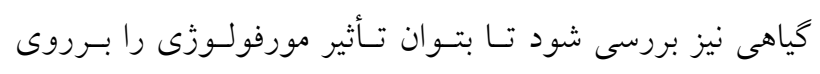

$$
\text { ضريب بِا بهتر بررسى كرد. }
$$

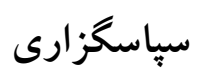

نويسندكان بر خود لازم مىدانند كه بدينوسـيله از حمايستهـاى بىدريغ جناب آقاى بروفسور زنستس، رياسـت محتـرم دانشـكده

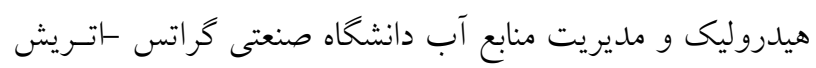

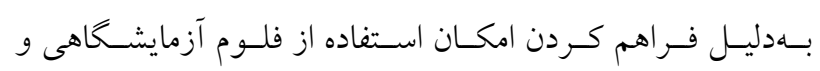
تجهيزات اندازهيرى سرعت، قدردانى و تشـكر كنتـد. همجٍنـين

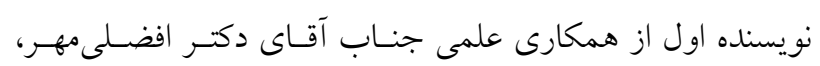
استاد دانشخاه صنعتى اصفهان، بسيار تشكر مى كند.
سرعت برشى ميانخين (به روش ميانخين حسـابى و دو گانـه) در محاسبه ضريب يُسا بسيار مؤثر است. در اين تحقيق بهجاى بررسى ضرايب يساى متعددى در يك

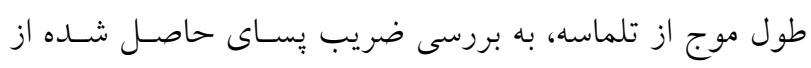

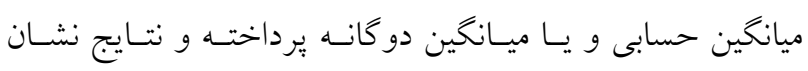
مى دهد كه ضريب بِاى متوسط حاصل شده از روش ميـانكين

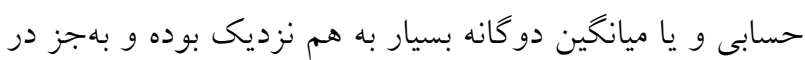
يك مورد، كمتر از ^ درصد اختلاف دارند. نتايج حاصل از تغييـر شـرايط هيـدروليكى جريـان نزديـى بستر و ضريب يسا بهصورت زير جمعبندى مىشود: افزايش دبى در تلماسههاى تاج تخت و تيـز، تـأثير جنــان

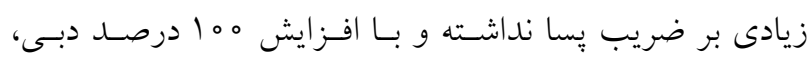
ميزان ضريب بِّا حداكثر (ها درصد) كاهش مى يابد.

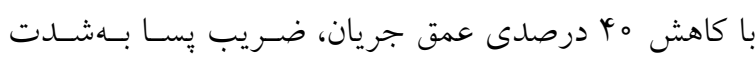
افزايش يافته و تا سقف 94 درصد زياد مىشود. كاهش قطر ذرات بستر سبب افـزايش ضـريب يُّـا شـده و اين تغيير در تلماسههاى تـاج تخـت حسدود تلماسهها با تاج تيز V + درصد براورد مىشود.

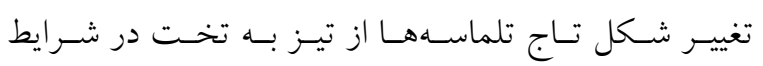
هيدروليكى مشابه، سبب افزايش ضريب بِا مىشود. اين ميزان

\section{منابع مورد استفاده}

ا. داوريناه، ش. هوسا. بررسى برهمكنش شكلهاى بستر شنى با تاج مسطح و يوشش كياهى ديوار بر مولفهاى جريان آشفته. ياياننامه كارشناسى ارشد آبيارى و زهكشى. دانشخاه صنعتى اصفهان. اصفهان.

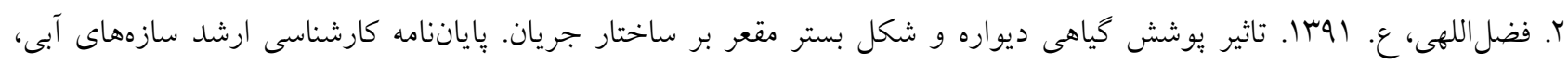
دانشكده كشاورزى، دانشخاه صنعتى اصفهان. اصفهان.

r. معتمدى، الف. و ح. افضلى مهر. זوهبا. بررسى برهمكنش هندسه تلماسه بر ساختار جريان و طول ناحيه جدايى با استفاده از

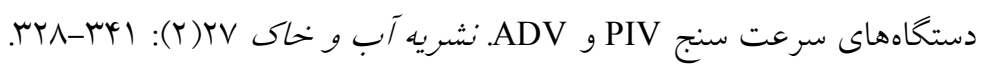

4. Afzalimehr, H., V. P. Singh and E. Fazel Najafabadi. 2010. Determination of form friction factor. Journal of Hydraulic Engineering 15: 3: 237-243.

5. Alonso, G. and J. Meseguer. 2006. A Parametric Study of the Galloping Stability of Two-dimensional Triangular Cross-section Bodies Journal of Wind Engineering and Industrial Aerodynamics 94(4): 241-253.

6. Best, J. and R. Kostaschuk. 2002. An experimental study of turbulent flow over a low angle dune. Journal of Geophysical Research: Oceans 107(C9). 
7. Darby, S. E. 1999. Effect of riparian vegetation on flow resistance and flood potential. Journal of Hydraulic Engineering 125: 443-454.

8. Dinehart, R. L. 1992. Evolution of coarse gravel bedforms: field measurements at flood stage. Water Resources Research 28: 2667-2689.

9. Hygelund, B. and M. Manga. 2003. Field measurements of drag coefficients for model large woody debris. Geomorphology 51(1): 175-185.

10. Jellesma, M. 2013. Form drag of subaqueous dune configurations. MSc. Thesis. University of Twente, Enschede.

11. Morinaga, T., N. Tanaka, J. Yagisawa, S. Karunaratne and W. M. S. B. Weerakoon. 2013. Estimation of drag coefficient of trees considering the tree bending or overturning situations. In: Proceeding of the International Symposium on Advances in Civil and Environmental Engineering Practices for Sustainable Development (ACEPS), University of Ruhuna, Sri Lanka. PP: 142-149.

12. Motamedi A., H. Afzalimehr, G. Zenz and M. Galoie. 2012. RANS simulations of flow over dune with low lee and sharp lee angles. In: Proceeding of the International SimHydro Conference, France.

13. Motamedi, A., H. Afzalimehr, V. Singh and L. Dufresne. 2012. Experimental study on the influence of dune dimensions on flow separation. Journal of Hydrologic Engineering 19(1): 78-86.

14. Motamedi, A., H. Afzalimehr, J. Gallichand and E. Fazel. 2012. Lee angle effects in near bed turbulence: An experimental study on low and sharp angle dunes. International Journal of Hydraulic Engineering 1(6): 68-74.

15. Ojha S. P. and B. S. Mazumder. 2008. Turbulence characteristics of flow region over a series of 2-D dune shaped structures. Advances in Water Resources 31: 561-576.

16. Olsen, N. R. B. 2011. A Three-Dimensional Numerical Model for Simulate of Sediment Movements in Water Intakes with Multiblock Option. Users`s Manual, by Nils Reidar B. Olsen, Department of Hydraulic and Environmental Engineering, The Norwegian University of Science and Technology. Trondheim, Norway.

17. Sadraey, M. 2009. Aircraft Performance: Analysis. VDM Publishing. chapter 3. Drag Force and Drag Coefficient. Saarbrucken VDM Verlag Dr. Muller Publishing. Germany.

18. Tanaka, N., H. Takenaka, J. Yagisawa and T. Morinaga. 2011. Estimation of drag coefficient of a real tree considering the vertical stand structure of trunk, branches, and leaves, International Journal of River Basin Management 9(3-4): 221-230.

19. Van-Dam, C. P. 1999. Recent experience with different methods of drag prediction. Aerospace 35(8): 751-798. 


\title{
Experimental Measurement and Numerical Model of Dunes Drag Coefficients
}

\author{
A. Motamedi ${ }^{*}$ and M. Galoie ${ }^{1}$
}

(Received: October 5-2016; Accepted: May 27-2017)

\begin{abstract}
In order to investigate the flow formation on dunes, the experimental data from a flume 12 meters long, located in Hydraulic Lab at Technical University of Graz (Austria), were collected. In this study, dunes (particle sizes of 13 and 6 $\mathrm{mm}$ ) in a 2-D plan were developed with the wavelength of 1 meter, the lee angle of 8 degree, and the crest heights of 4 and $6 \mathrm{~cm}$; these were uniformly installed across the width of flume. The analysis of the experimental flow velocity profiles measured by ADV and PIV technology and the numerical profiles modeled by SSIMM showed that in the same hydraulic conditions, there was no significant relation between drag coefficients of particles on dunes and flow discharge variation, while the water depth reduction caused a sudden increase in the drag coefficient up to 66\%. Also, reducing particle size of the dune increased the drag coefficient and there was a significant relation between particle size (diameter) and dune formation, so that in smooth crested conditions, as compared with the sharp crested dune, the drag coefficient was increased up to $32 \%$.
\end{abstract}

Keywords: Dune dimensions, Drag Coefficient, Shear Velocity, Double-Averaging

1. Civil Engineering, Architecture and Urban Planning Department, Technical University of Buein Zahra, Qazvin, Iran.

*: Corresponding Author, Email: Artemis.mot@bzte.ac.ir 